\title{
Socio-demographic characteristics of rural producers of the Mexicali municipality, Baja California: a comparative approach
}

\author{
José Zavala Álvarez ${ }^{1 *}$ \\ Eduardo Sánchez López ${ }^{2}$ \\ Jesús Francisco Sosa Gordillo \\ Ruth Beatriz Rodríguez Maciel $^{3}$
}

\begin{abstract}
The objective of this work is to prepare a comparative descriptive analysis of socio-demographic characteristics of rural producers in the municipality of Mexicali, Baja California, using two sources with temporal proximity: the Survey of Rural Producers of the Municipalities of Baja California and the last Agricultural Census. The thematic and territorial disaggregation that is carried out is of importance due to the notable shortage and need, in northern Mexico, of regional and local knowledge to plan regional and rural agricultural development. The variables considered are: producer and family size, expenditure, productive problems, age and gender, schooling, professionalization and technical training, complementary producer and family occupations. It was found that the vast majority of producers are still smallproducers, their household expenditure is clearly low, their main problems lie in the cost of inputs and there is a delicate warning due to advanced age, low schooling and training that adds up to a low proportion of possible replacement as producers in the subsequent generation which has a preference for a way of life other than agricultural activity.
\end{abstract}

Keywords: Rural producers, socio-demographic, agricultural.

\section{Características sociodemográficas de productores rurales del municipio de Mexicali, Baja California: una aproximación comparada}

\section{Resumen}

El objetivo de este trabajo fue elaborar un análisis descriptivo comparado de características sociodemográficas de productores rurales del municipio de Mexicali, Baja California, se utilizaron dos fuentes con proximidad temporal: la Encuesta a Productores Rurales de los municipios de Baja California y el último Censo Agropecuario. La desagregación temática y territorial que se lleva a cabo resulta de importancia por la notable escasez y necesidad de conocimiento regional y local para la planeación del desarrollo agrícola regional y rural en el norte mexicano. Las variables en cuenta son: tamaño del productor y la familia, gasto, problemas productivos, edad y género, escolaridad, profesionalización y capacitación técnica, ocupaciones complementarias del productor y familiares. Se encontró que la gran mayoría de los productores son aún de tamaño reducido, su gasto familiar es claramente bajo, sus principales problemas radican en el costo de los insumos y hay una advertencia delicada por la edad avanzada, la baja escolaridad y capacitación que se suma a una baja proporción de posible reemplazo como productores en la generación subsecuente la cual tiene preferencia por un modo de vida distinto a la actividad agrícola.

Palabras clave: Productores rurales, sociodemográficos, agropecuario.

'El Colegio de la Frontera Norte. Fraccionamiento Hega, Mexicali, B. C.

${ }^{2}$ Instituto de Investigaciones en Ciencias Veterinarias, UABC. Prol. Calle Campestre s/n. Fracc. Laguna Campestre, Mexicali, B. C., C. P. 21386, México.

${ }^{3}$ El Colegio de la Frontera Norte, km 18.5 carr. Tijuana-Ensenada, San Antonio del Mar, Tijuana, B. C., C. P. 22560, México.

*Corresponding author: jza61@colef.mx, cel. 6865432324

Received: July 14, 2019.

Accepted: February 27, 2020 


\section{Introduction}

Knowledge about the socio-demographic conditions of rural areas is essential so the problems of the subject of development in rural areas can be approached, the need to have disaggregated information at a regional level "with close and practical indicators to identify opportunities for government intervention... and decision making in public policies" has been documented by several authors (Torres, 2006; Leyva, Gastélum, \& López, 2015; Calvo \& Aguado, 2012).

However, the available instruments and means to generate knowledge about these phenomena are always insufficient, the agricultural and livestock census carried out by the Instituto Nacional de Estadística y Geografía (National Institute of Statistics and Geography, INEGI, by its acronym in Spanish) gathers socio-demographic information on a limited basis and loses focus on the subject of development and their families because they use "Production Units" as observation units (INEGI, 2008a), in addition to the precarious way they have been carried out and canceled, there was a sixteen year gap between the 1991 and 2007 census (the latter must have been carried out in 2001), the census programed for 2017 was also canceled even though the sampling framework was updated in 2016.

Under these circumstances, which have become constant, the periodical and systematic interruption of obtaining basic information to plan the regional development, becomes a severe problem, thus INEGI's decision to conduct the Encuestas Nacionales Agropecuarias (Agricultural and Livestock National Surveys, ENA, by its acronym in Spanish) in 2012 and 2014; later on, the biannual period of conducting the third edition was interrupted, which took place until 2017 in substitution of the canceled census. The objective of the ENA has been "to obtain updated agricultural and livestock statistical information about the production of the 33 main agricultural and livestock products in the country" and their restriction in terms of socio-demographic information about producers and their families are the same as those of the census because they have the same type of questionnaire (INEGI, 2013).

In addition to the aforementioned circumstances, it is necessary to note the physical and financial difficulties of the 2007 Census, while it was

\section{Introducción}

El conocimiento sobre las condiciones sociodemográficas del medio rural son imprescindibles para el abordaje de los problemas de los sujetos del desarrollo en el territorio rural, la necesidad de contar con información desagregada a nivel del espacio regional "con indicadores cercanos y prácticos, para identificar oportunidades de intervención gubernamental... y toma de decisiones de política pública" ha sido documentada por numerosos autores (Torres, 2006; Leyva, Gastélum, \& López, 2015; Calvo \& Aguado, 2012).

Sin embargo, los instrumentos y medios disponibles para generar conocimiento sobre estos fenómenos son siempre insuficientes, los censos agropecuarios levantados por el Instituto Nacional de Estadística y Geografía (INEGI) recogen de manera limitada información sociodemográfica y pierden el foco del sujeto del desarrollo y sus familias, pues utilizan como unidades de observación a las "Unidades de Producción" (INEGl, 2008a), a esto hay que sumar la precariedad con que han sido levantados y suspendidos, hubo dieciséis años entre los censos de 1991 y 2007 (este último debió haberse levantado en 2001), el censo programado para 2017 finalmente también se canceló a pesar de que se hicieron trabajos de actualización del marco muestral en 2016.

Frente a estas circunstancias, que se van haciendo constantes, la interrupción periódica, sistemática, en la obtención de información básica para la planeación del desarrollo regional se convierte en un grave problema, de ahí la decisión de INEGI de levantar las Encuestas Nacionales Agropecuarias (ENA) en los años de 2012 y 2014, posteriormente se interrumpió el periodo bianual de levantamiento de la tercera edición llevándose a cabo hasta 2017 en sustitución del censo cancelado. El objetivo de las ENA ha sido "obtener información estadística actualizada de la producción agropecuaria, de los 33 principales productos agropecuarios en el país" y sus limitaciones en materia de información sociodemográfica respecto de los productores y sus familias, son las mismas que las de los censos debido a que comparten el diseño del cuestionario (INEGI, 2013).

Adicionalmente a las circunstancias señaladas es necesario anotar las dificultades materiales 
conducted, several brigade members acknowledged that they did not do approximately $20 \%$ of the work', this has a negative effect on the validity of the data.

The need to obtain socio-demographic, rural and agricultural information at a regional, local and municipal level; as Torres (2006) sustains, it is common to underuse data and characteristic techniques of the socio-demographic analysis because demographic techniques are less developed and the use of geographic information systems is needed and are not always available; and these were used to register and carry out the Encuesta Estatal a Productores del Sector Rural in the municipalities of Baja California (State Survey to Producers from the Rural Sector, ENEP Rural, by its acronym in Spanish) in 2008, as an instrument of the Estudio de Estratificación Regional de Productores del Sector Rural (Regional Stratification Study of Producers in the Rural Sector) in the municipalities of Baja California carried out by El Colegio de la Frontera Norte (Colef, Produce B.C., 2008) ${ }^{2}$.

The general objective of this research was to carry out a comparative descriptive analysis of the sociodemographic characteristics of rural producers in the municipality of Mexicali, Baja California, using both sources with temporal proximity: the Censo Agrícola, Ganadero y Forestal (Agricultural, Livestock and Forestry Census) INEGI in 2007, which was the last one to be carried out and the ENEP Rural in 2008 whose information refers back to the 2007 agricultural year.

The conceptual categories and variables have differences and similarities, but these conditions are not uncommon, there are always restrictions in the available information, especially regarding rural areas and their social actors emphasized in the northern part of Mexico. The challenge is to carry out useful disciplinary exercises to generate knowledge about the reality of the rural subjects in order to provide knowledge to plan the development in the regional and local rural territory, to elaborate strategic recommendations towards improving the

'Statements of brigade members from INEGI during the months the information was gathered and coincided with those of ENEP Rural.

${ }^{2}$ The study received funding from Fundación Produce for the Agricultural, Livestock, Forestry and Fishery Research in Baja California (Produce B.C.). y presupuestarias del Censo de 2007, durante el levantamiento varios brigadistas reconocían no haber realizado aproximadamente el $20 \%$ del trabajo', esto significa un efecto negativo en la validez de los datos producidos.

Debido a la necesidad de obtener información sociodemográfica, rural, agrícola, en el plano regional, local, municipal; como sostiene Torres (2006), es común que los datos y técnicas característicos del análisis sociodemográfico sean subutilizados debido a que las técnicas demográficas están menos desarrolladas y se requiere de la utilización de sistemas de información geográfica que no siempre están disponibles; y es en las que se inscribe el levantamiento de la Encuesta Estatal a Productores del Sector Rural de los municipios de Baja California (ENEP Rural) en 2008, como instrumento del Estudio de Estratificación Regional de Productores del Sector Rural de los municipios de Baja California realizado por El Colegio de la Frontera Norte (Colef, Produce B.C., 2008) ${ }^{2}$.

El objetivo general de este trabajo fue hacer un ejercicio de análisis descriptivo comparado de los rasgos sociodemográficos de los productores rurales del municipio de Mexicali, Baja California, utilizando esas dos fuentes que tienen proximidad temporal: el Censo Agrícola, Ganadero y Forestal INEGI de 2007, el cual es el último hecho, y la ENEP Rural de 2008 cuya información está referenciada al ciclo agrícola 2007.

Las categorías conceptuales y las variables tienen diferencias y similitudes, pero estas condiciones no son poco comunes, siempre hay limitaciones en la información disponible especialmente sobre el medio rural y sus actores sociales acentuándose en el norte de México. El reto es realizar ejercicios disciplinarios útiles para generar conocimiento de la realidad de los sujetos rurales con la intención de proveer conocimiento para la planeación del desarrollo en el territorio rural regional y local, para la elaboración de recomendaciones estratégicas en la dirección para mejorar las condiciones en las que llevan a cabo sus actividades los productores y sus

'Señalamientos de brigadistas de INEGI en los meses de levantamiento que coincidieron con los de la ENEP Rural.

2El estudio recibió auspicios de la Fundación Produce para la Investigación Agropecuaria, Forestal y Pesquera de Baja California (Produce B.C.). 
conditions where the producers and their families carry out their activities as well as the overall development of the social sector.

Schejtman y Berdegué (2004) say that in search of new answers, the "territorial approach of rural development" has gained strength, however, the institutions have not yet developed suitable policies for the productive and instructional transformation in a rural space where its aim is to reduce poverty. Gómez and Tacuba (2017) reinforce this argument in the sense that the dimension of the development as social progress, does not only refer to the quantity of production, the best foundation to analyze rural areas is to start by measuring to characterize poverty as a basis and reason for public planning directed towards the expansion of human capacities.

Measuring problems of the development are based on the fact that many technicians want to encase the rural development model as an econometrics instrument that pretends to evaluate societies in order to diagnose investment actions, confusing what it means to plan the development and the subject of development, a development which creates itself is not mentioned, these are programs attached to external models outside the will of those affected, as Zambrano, Trujillo and Solórzano (2015) sustain, these authors also mention that an institutional system that works according to the guidelines of sustainable development, is a system able to generate mechanisms that will allow active participation from the citizens; meaning, from the wide variety of social actors that form the rural society, regardless of their age, gender, cultural and ethnic ascription or affiliation to an organization.

The purpose of this study is to identify and analyze the dimensions of each socio-demographic characteristic, considered as relevant, of the producers and their families in their condition of subjects of development. A critical and descriptive analysis is elaborated and it highlights findings that warn about conditions or situations that put at risk or enhance the viability of the development of this socio-demographic group.

It is sensible to outline the importance of the knowledge obtained from the ENEP Rural which is relevant, it is valuable because it constitutes a reference point to know the regional reality of the familias, así como en el desarrollo en general de este sector social.

Schejtman y Berdegué (2004) afirman que en la búsqueda de nuevas respuestas el "enfoque territorial del desarrollo rural" ha cobrado fuerza, sin embargo, las instituciones aún no han desarrollado las políticas adecuadas, para la transformación productiva e instruccional en un espacio rural cuyo alcance sea reducir la pobreza. Gómez y Tacuba (2017) refuerzan el argumento en el sentido de que la dimensión de desarrollo como progreso social, no es solo la cantidad de producción, la mejor base para analizar el medio rural es partiendo de la medición para caracterizar la pobreza, como fundamento y razón de la planeación pública, dirigida a la expansión de las capacidades humanas.

Los problemas de medición del desarrollo se basan en el hecho de que muchos técnicos han querido encajonar el modelo de desarrollo rural como un instrumento econométrico que pretende evaluar a las sociedades con el fin de diagnosticar acciones de inversión, confundiendo lo que es planificar el desarrollo y el sujeto de desarrollo, no se habla de un desarrollo que sea creador en sí mismo, son programas atados a modelos externos fuera de la voluntad de los afectados, según lo sostienen Zambrano, Trujillo y Solórzano (2015), estos autores señalan, también, que un sistema institucional que funciona según las pautas del desarrollo sostenible, es un sistema capaz de generar mecanismos que permitan la participación activa de la ciudadanía; es decir, de toda la gama de actores sociales que conforman la sociedad rural, independientemente de su edad, género, adscripción cultural y étnica o filiación organizativa.

En el presente estudio se propone identificar y analizar las dimensiones de cada rasgo sociodemográfico, considerado como relevante, de los productores y sus familias en su condición de sujetos del desarrollo. Se elabora un análisis crítico descriptivo y destaca hallazgos que advierten condiciones o situaciones que ponen en riesgo o potencian la viabilidad del desarrollo de este grupo demográfico.

Es prudente subrayar la importancia del conocimiento obtenido a partir de la ENEP Rural que cobra actualidad, es tanto sostenido como valioso 
rural subjects with more detail and thoroughness, something that the precariousness and the interruption of the census makes it severely difficult, therefore recovering the information, building data and generating useful knowledge is transcendental so subsequent research can resume and carry out comparative studies in the crucial task of measuring development.

\section{Materials and methods}

This research is exploratory because the topic is poorly studied and the socio-demographic characterization builds questions for future studies. It is transversal because it is only one measurement, even though it has the potential purpose of being useful as a comparative reference for longitudinal studies (Méndez, Namihira, Moreno, \& Sosa, 1993). It is a documentary investigation because concepts and definitions already proposed and used, that generate new knowledge and analysis, are utilized and it defines variables and indicators or units of observation. It is also a descriptive investigation because it proposes to describe socio-demographic characteristics.

This study uses theoretical and empirical methods. The theoretical method refers to the deductive method that enables the analysis of variables through the observation or indicator units. The empirical method is the measurement of data from a survey or a census and the characterization of variables in a comparative analysis exercise.

The research work has quantitative and qualitative tools.

\section{Study area and tools to obtain information}

The research comprises two sources of information, the Censo Agrícola, Ganadero y Forestal of INEGI in 2007 and the Encuesta Estatal a Productores Rurales of the municipalities in Baja California (ENEP Rural) in 2008 by authorship of El Colef and whose data base was integrated in 2009, socio-demographic variables were taken from these sources to carry out an exercise of comparative descriptive analysis, the chosen variables have a conceptual and temporary approximation considered as useful for the purposes of this work, it is important to keep in mind that this is the available information. pues constituye un punto de referencia para el conocimiento de la realidad regional de los sujetos rurales con mayor profundidad y detalle, algo que la precariedad y la interrupción de los censos dificulta de manera grave, de ahí la trascendencia de recuperar la información, la construcción de datos y la generación de conocimiento útil y que trabajos posteriores puedan retomar para efecto de estudios comparativos en la tarea crucial de medición del desarrollo.

\section{Materiales y métodos}

Esta investigación es de tipo exploratoria por el tema poco estudiado y en el que la caracterización sociodemográfica construye preguntas para estudios posteriores. Es transversal debido a que es una sola medición, aunque tiene el propósito potencial de servir como referencia comparativa para estudios longitudinales (Méndez, Namihira, Moreno, \& Sosa, 1993). Es investigación documental en tanto se usan conceptos y definiciones ya propuestos y utilizados que generan nuevos conocimientos y análisis, y define variables e indicadores o unidades de observación. Es también investigación descriptiva en tanto se propone describir rasgos sociodemográficos.

El estudio utiliza métodos teóricos y empíricos. El teórico se refiere al método deductivo que permite el análisis de las variables a través de las unidades de observación o indicadores. El método empírico es lo relativo a la medición de los datos provenientes de una encuesta y de un censo y, la caracterización de las variables respectivas en un ejercicio de análisis comparativo.

El trabajo de investigación contiene herramientas cuantitativas y cualitativas.

\section{Área de estudio e instrumentos de obtención de información}

La investigación comprende dos fuentes de información, el Censo Agrícola, Ganadero y Forestal de INEGI de 2007 y la Encuesta Estatal a Productores Rurales de los municipios de Baja California (ENEP Rural) en 2008, de autoría propia en El Colef, y cuya base de datos fue integrada en 2009, de estas dos fuentes se tomaron variables sociodemográficas para efectos de un ejercicio de análisis descriptivo comparado, las variables elegidas tienen la 
In the particular case of the ENEP Rural, the field work was carried out between March and May in the five municipalities of Baja California were one thousand questionnaires were applied.

Spatially, the study circumscribes the agricultural area of the municipality of Mexicali, the most important in number of producers and agricultural extension, "it is located in the delta of the Colorado river in the state of Baja California and partially with Sonora, it has 207965 hectares with irrigation rights -from which 26647 are found in Sonora-, it is part of the 014 Irrigation District, one of the first four most distinct districts in the country, ${ }^{3}$ this surface belongs to 15177 people with rights to land and water" (Sánchez, 2003).

The ENEP Rural derives from the research project "Estudio de estratificación regional de productores del sector rural de los municipios de Baja California".

\section{Population and sample}

The sample was obtained from a sampling framework formed from the census provided by the Secretaría de la Reforma Agraria (SRA, by its acronym in Spanish) and partially from Comisión Nacional del Agua (CNA, by its acronym in Spanish) and at a state level it comprised a population of 14 498 ejidatarios and 5587 settlers, from which a total of 12152 producers correspond to the municipality of Mexicali: 7782 ejidatarios and 4372 settlers (SRA, 2008; CNA, 2008).

A simple random sampling design without replacement is considered in order to obtain a representative sample of ejidatarios and settlers from the municipalities of the state. It is important to specify that at the end 14273 ejidatarios were considered to calculate the size of the sample, because those who have registered 0 hectares were excluded.

The sample size for the ejidatarios, assuming they are all producers, was calculated in 500 interviews, an it was taken from the distribution by size of land according to the information given: $51.3 \%$ of the ejidatarios have 10 or less hectares, and $48.7 \%$ have more than 10 hectares, and an estimation error of $4.38 \%$

\footnotetext{
${ }^{3}$ The four most extensive irrigation districts: Bajo Río Bravo in Tamaulipas, with almost 286 thousand hectares, Valle del Río Fuerte in Sinaloa with 267 thousand hectares, Valle del Yaqui in Sonora with 260 thousand, and Río Colorado with practically 208 thousand (SARH, 1976).
}

aproximación conceptual y temporal que para efectos de este trabajo se consideran útiles, aquí es importante tener en cuenta que es la información que está disponible.

En el caso particular de la ENEP Rural, esta se levantó en campo entre los meses de marzo a mayo en los cinco municipios de Baja California donde se aplicaron mil cuestionarios.

Espacialmente el estudio se circunscribe a la región agrícola del municipio de Mexicali, el de mayor importancia en número de productores y extensión agrícola, "está localizada en el delta del río Colorado, en el estado de Baja California y parcial de Sonora, cuenta con 207965 hectáreas con derechos de riego -de las cuales 26647 se encuentran en Sonora-, constituye el Distrito de Riego 014, uno de los cuatro primeros distritos más extensos del país, ${ }^{3}$ esta superficie pertenece a 15177 personas con derechos de agua y tierra" (Sánchez, 2003).

La ENEP Rural se deriva del proyecto de investigación "Estudio de estratificación regional de productores del sector rural de los municipios de Baja California".

\section{Población y muestra}

La muestra se obtuvo a partir de un marco muestral conformado a partir de los padrones proporcionados por la Secretaría de la Reforma Agraria (SRA) y parcialmente por la Comisión Nacional del Agua (CNA) y que a nivel estatal conformaron una población de 14498 ejidatarios y 5587 colonos, de los cuales corresponden al municipio de Mexicali un total de 12152 productores: 7782 ejidatarios y 4372 colonos (SRA, 2008; CNA, 2008).

Se considera un diseño de muestreo aleatorio simple sin reemplazo, con la finalidad de obtener una muestra representativa de los ejidatarios y colonos de los municipios del estado. Cabe precisar que finalmente se tomaron en consideración para el cálculo del tamaño de la muestra 14273 ejidatarios, pues se excluyeron aquellos que tienen registro de cero hectáreas.

\footnotetext{
${ }^{3}$ Los cuatro distritos de riego más extensos: Bajo Río Bravo en Tamaulipas, con casi 286 mil hectáreas, el Valle del Río Fuerte en Sinaloa con 267mil hectáreas, el Valle del Yaqui en Sonora con 260 mil, y el Río Colorado con prácticamente 208 mil (SARH, 1976).
} 
and a confidence level of $65 \%$. From that state total, 278 cases correspond to the municipality of Mexicali.

Regarding the settlers, the available information is included at a colony level, with the number of beneficiaries and hectares; and assuming a uniform distribution regarding the number of hectares, the sample size is calculated in 500 interviews, which according to the information provided, $93.8 \%$ of the settlers have 10 or less hectares and $6.2 \% 10$ or more, an estimation error of 2.11 and $95 \%$ confidence. The sample of settlers from the municipality of Mexicali was of 426. Considering the latter information, the total number of questionnaires applied in the municipality of Mexicali was of 704 .

\section{Observation units}

Regarding the Agricultural and livestock Census, the observation unit is the Production Unit (PU), conceptualized as "the group formed by land with or without agricultural, livestock or forestry activity in the rural area or with agricultural and livestock activity in the urban area, located in the same municipality; the animals owned or raised for their meat, milk, eggs, skin, honey or work, regardless of the place where they are located; as well as the equipment, machinery and vehicles destined to agricultural, livestock or forestry activities; as long as it is all managed by the same administration from March to September 2007" (INEGI, 2009).

The observation unit of the ENEP Rural is the subject, the rural producer understood as the person who has the legal right, who is the main owner of the land in the rural area and who was active in its property during the agricultural cycle of 2007 and in others where it had the usage right through other mechanisms such as lease, loan, in association or collective property.

Socio-demographic variables included in the 2007 Censo Agrícola, Ganadero y Forestal

The tabulators of the Census are shown in Production Units (PU), the socio-demographic variables it contains are:

1. Origin of the total income of the producer. PU with income from agricultural, livestock and forestry activity, remittances from other
El tamaño de muestra para los ejidatarios suponiendo que todos sean productores se calculó en 500 entrevistas, y esta se tomó a partir de la distribución por tamaño del predio según la información proporcionada: $51.3 \%$ de los ejidatarios tienen 10 o menos hectáreas, y $48.7 \%$ tienen más de 10 hectáreas, un error de estimación de 4.38 y un nivel de confianza del $95 \%$. De ese total estatal, 278 casos corresponden al municipio de Mexicali.

Para el caso de los colonos la información que se tiene se encuentra agregada a nivel de colonia, con el número de beneficiados y hectáreas, y suponiendo una distribución uniforme en cuanto al número de hectáreas; el tamaño de muestra se calcula en 500 entrevistas, que de acuerdo a la información proporcionada, el $93.8 \%$ de los colonos tienen 10 o menos hectáreas y el $6.2 \% 10$ o más, un error de estimación de 2.11 y el $95 \%$ de confianza. La muestra de colonos correspondiente al municipio de Mexicali fue de 426. Tomando en cuenta lo anterior, el número total de cuestionarios aplicados en el municipio de Mexicali fue de 704.

\section{Unidades de observación}

En el caso del Censo Agropecuario, la unidad de observación es la Unidad de Producción (UP), conceptualizada como "el conjunto formado por los terrenos con o sin actividad agropecuaria o forestal en el área rural o con actividad agropecuaria en el área urbana, ubicados en un mismo municipio; los animales que se posean o críen por su carne, leche, huevo, piel, miel o para trabajo, independientemente del lugar donde se encuentren; así como los equipos, maquinarias y vehículos destinados a las actividades agrícolas, pecuarias o forestales; siempre que durante el periodo de marzo a septiembre de 2007, todo esto se haya manejado bajo una misma administración" (INEGI, 2009).

La unidad de observación en la ENEP Rural es el sujeto, el Productor Rural, entendido como la persona que tiene derecho legal, que es propietario titular de predios en el medio rural y que durante el ciclo agrícola 2007 estuvo activo en su propiedad y en otras sobre las que tuvo derecho de uso por medio de otros mecanismos como renta, préstamo, en asociación o propiedad colectiva. 
countries, government support and another activity.

2. Age of the producer.

3. Sex and indigenous language of the producer. PU according to sex if the producer or their relatives speak an indigenous language.

4. The producer's schooling and level of academic studies passed. PU with producers with different schooling levels.

5. Members who economically depend on the producer, younger and older than eighteen years old differentiated by sex.

6. Services and characteristics of the producer's house. PU according to availability of services and characteristics of the house.

7. Even though they are not included within the classification of "socio-demographic characteristics" in the Agricultural and Livestock Census, due to the interest of the analysis to relate proximal variables, two additional variables were considered in this study:

8. Main problems to develop agricultural, livestock or forestry activities. PU with losses due to climatic issues, expensive supplies and services, loss of soil fertility, difficulty to have access to loans, lack of training and technical assistance, marketing, insufficient infrastructure, slightly suitable organization, difficulty to accredit ownership of land, litigation for land.

9. Relatives of the producer involved in agricultural, livestock or forestry activities.

\section{Socio-demographic variables from ENEP Rural}

The socio-demographic data generated by ENEP Rural are:

1. Size of the producer. Sizing the producer using the Annual Value of the Agricultural Production.

2. Family size. Sizing a family by the number of family members.

3. Monthly household expenditure. Monthly household expenditure as reported by the producer in 2008 Mexican pesos.

4. Main problems of the producer. Main identified difficulties to carry out the agricultural activity: supply costs, water, support, financing, harvest price.
Variables sociodemográficas incluidas en el Censo

Agrícola, Ganadero y Forestal 2007

Los tabuladores del Censo están referidos en Unidades de Producción (UP), las variables sociodemográficas que contiene son:

1. Origen de los ingresos totales del productor. UP con ingresos provenientes de actividad agropecuaria y forestal, remesas de otro país, apoyo gubernamental y otra actividad.

2. Edad del productor.

3. Sexo del productor y lengua indígena. UP según sexo y si el productor o sus familiares hablan alguna lengua indígena.

4. Escolaridad y nivel de estudios aprobado del productor. UP con productores con diferente nivel de escolaridad.

5. Dependientes económicos del productor. Personas dependientes económicos del productor menores y mayores a dieciocho años diferenciadas por sexo.

6. Servicios y características de la vivienda del productor. UP según disponibilidad de servicios y características de la vivienda.

7. Aun y cuando en el Censo Agropecuario no están dentro de la clasificación de "características sociodemográficas", por interés del análisis en relacionar variables próximas, en este trabajo se consideraron dos adicionales:

8. Problemática principal para desarrollar la actividad agropecuaria o forestal. UP con problemas de pérdidas por cuestiones climáticas, alto costo de insumos y servicios, pérdida de fertilidad del suelo, difícil acceso al crédito, falta de capacitación y asistencia técnica, comercialización, infraestructura insuficiente, organización poco apropiada, dificultad para acreditar posesión de la tierra, litigios por la tierra.

9. Familiares del productor con participación en actividad agropecuaria y forestal. UP con miembros de la familia que participan en la actividad productiva.

Variables sociodemográficas de la ENEP Rural Los datos sociodemográficos que la ENEP Rural genera son:

1. Tamaño del productor. El dimensionamiento utilizando el Valor Anual de la Producción Agrícola. 
5. Age and gender of the producer. Age in years and gender.

6.Schooling by gender of the producer. The grade of schooling measured by six levels: without schooling, primary or any primary grade studied. Secondary or any secondary grade studied, high-school or any highschool grade studied, college or any year of college studied, and post-graduate school or any year of post-graduate school studied, specialization or diploma courses.

7. Professionalization or technical training of the producer. Identifying the profession or technical studies.

8. Complementary occupations of the producer. Identification of occupations complementing that of agriculture.

9.Professionalization or technical training of family members. Identification of a profession or technical training of family members, excluding the producer.

10. Occupation of other family members. Identifying the occupation of the family members, including agricultural activity.

\section{Results and discussion}

Comparing the relation between characteristics and variables from both sources, first of all, it can be seen that the ENEP Rural is focused on the producer as subject of development, meanwhile, the Census makes the information unpersonal by having a $\mathrm{PU}$ as an observation unit.

The ENEP Rural has a larger number of variables which represent more information, pertinence and thoroughness to analyze and characterize the sociodemographic conditions of rural producers. It is necessary to acknowledge that some relevant data in the Census, such as housing and availability of services are not included in the ENEP Rural.

Even though the Census gathers data regarding age of the producer in its reports and tabulators, it was not incorporated, the ENEP Rural gathers it and presents it clearly as a preponderating part of the information and analysis.

The data selected from both sources using variables of the ENEP Rural as a discussion script is presented below, an organized tour is
2. Tamaño de la familia. El dimensionamiento de la familia a través del número de miembros.

3. Gasto familiar mensual. Monto del gasto familiar mensual que señala el productor, en pesos mexicanos de 2008.

4. Principales problemas del productor. Principales dificultades que identifica para realizar su actividad agrícola: costos de insumos, agua, apoyos, financiamiento, precios de cosecha.

5. Edad y género del productor. La edad en años y género.

6. Escolaridad por género del productor. Los grados de escolaridad medidos a través de seis niveles: sin escolaridad, primaria o algún año de primaria, secundaria o algún año de secundaria, preparatoria o algún año de preparatoria, universidad o algún año de universidad, y posgrado o algún año de posgrado, especialización o diplomado.

7. Profesionalización o capacitación técnica del productor. Identificación de profesión o estudios técnicos.

8. Ocupaciones complementarias del productor. Identificación de ocupaciones complementarias a la actividad agrícola.

9.Profesionalización o capacitación técnica de miembros de la familia. Identificación de alguna profesión o estudios técnicos de miembros de la familia excluyendo al productor.

10. Ocupaciones de otros miembros de la familia. Identificación de ocupaciones de miembros de la familia incluyendo la actividad agrícola.

\section{Resultados y discusión}

De la comparación de las relaciones de características y variables de las dos fuentes puede advertirse en primer término que la ENEP Rural se enfoca en el productor como sujeto del desarrollo, por su lado el Censo despersonaliza la información al sostener la UP como unidad de observación.

La ENEP Rural contiene un mayor número de variables que significan más información, pertinencia y profundidad para analizar y caracterizar las condiciones sociodemográficas de los productores rurales. Es necesario aceptar que algunos datos relevantes del Censo, como las condiciones de vivienda y disponibilidad de servicios, no están contenidos en la ENEP Rural. 
elaborated with a descriptive analysis of the proportions of the variables and are considered as findings worth highlighting, regarding some specific variables, a comparison effort is carried out taking into consideration the criterion of conceptual proximity, this effort is motivated by the purpose of contributing to the knowledge of the socio-demographic reality of rural producers in the region.

\section{Descriptive analysis and comparison between variables}

Size of the producer: Annual value of the agricultural production

Unlike the Agricultural and Livestock Census, which presents the PU with number and size of plots, in the ENEP Rural a clearer and direct form to show sizing of the producer was used through the Annual Agricultural Production Value, this variable is also an approximation of the producer's income ${ }^{4}$. The values obtained in each case (Table 1) show that more than half of the producers do not exceed an income of three hundred thousand pesos a year, as a matter of fact, one out of five producers do not make a hundred thousand, hardly one out of ten producers

${ }^{4}$ The net income (the result after subtracting individual production cost to the agricultural production value) is the most accurate measurement, in fact, it is extremely difficult to obtain this data.
A pesar de que el Censo reúne el dato de edad del productor en sus informes y tabulados, no fue incorporado, la ENEP Rural lo obtiene y lo presenta claramente como parte preponderante de la información y análisis.

Enseguida se presentan los datos seleccionados de las dos fuentes utilizando las variables de la ENEP Rural como guion de discusión, se elabora un recorrido organizado con un análisis descriptivo de las proporciones de las variables y que son consideradas como hallazgos que importa destacar, en el caso de algunas variables específicas se lleva a cabo un esfuerzo de comparación tomando en cuenta el criterio de proximidad conceptual, el empeño por este ejercicio está motivado por el propósito de abonar al conocimiento de la realidad sociodemográfica de los productores rurales de la región.

\section{Análisis descriptivo y comparación de variables}

\section{Tamaño del productor: Valor anual de la}

producción agrícola

A diferencia del Censo Agropecuario, que presenta UP con número y tamaño de predios, en la ENEP Rural se optó por una forma más clara y directa de mostrar el dimensionamiento del productor a través del Valor de la Producción Agrícola Anual, esta variable es también una aproximación al ingreso del

Table 1. Mexicali. Size of the producer in Annual Agricultural Production Value

Cuadro 1. Mexicali. Tamaño de productor en Valor de Producción Agrícola Anual

\begin{tabular}{lc}
\hline $\begin{array}{l}\text { Agricultural Production Value (pesos 2008) / } \\
\text { Valor de Producción Agrícola (pesos 2008) }\end{array}$ & \% of Producers / \% de Productores \\
\hline Less than 100000 / Menos de 100000 & 18 \\
From 100000 to 300000 / De 100000 a 300000 & 39 \\
More than 300000 to 500000 / Más de 300000 a 500000 & 16 \\
More than 500000 to 1'000 000 / Más de 500 000 a 1'000 000 & 12 \\
More than 1'000 000 to 2'000 000 / Más de 1'000 000 a 2'000 000 & 7 \\
More than 2'000 000 to 5'000 000 / Más de 2'000 000 a 5'000 000 & 2 \\
More than 5'000 000 / Más de 5'000 000 & 0.5 \\
*NC/NS & 5.5 \\
Total & \\
\hline
\end{tabular}

Source: Elaborated from ENEP Rural (2009). *NC=Did not answer/NS=Does not know

Fuente: Elaboración a partir de ENEP Rural (2009). 
Table 2. Mexicali: Size of the Family

Cuadro 2. Mexicali: Tamaño de la familia

\begin{tabular}{cc}
\hline Members / Miembros & \% of families / \% de familias \\
\hline 1 & 8.2 \\
2 & 19 \\
3 & 22.6 \\
4 & 21 \\
5 & 15.4 \\
6 & 6.7 \\
7 & 2.1 \\
8 & 1.5 \\
9 & 1 \\
NC/NS & 2.5 \\
Total & \\
\hline
\end{tabular}

Source: Elaboration from ENEP Rural (2009). *NC=Did not answer/NS=Does not know

Fuente: Elaboración a partir de ENEP Rural (2009).

make more than one million. These data show that most of the producers in Mexicali, three out of four are small-scale producers, clearly insufficient to have a dignified livelihood from their agricultural activity.

\section{Size of the family}

The variable Size of the Family (Table 2 ) provides clear data, they are not big families because more than 70 $\%$ do not have more than four members and only one out of 20 have more than 7. These data is similar to the information produced by the Census averaging three members, the producers and two economic dependents $s^{5}$. Therefore it is important to highlight that rural families with an agricultural activity are not numerous as it was predicted or even documented years ago. It is highly probable that the low levels of the production value and high cost of supplies have a reductive effect on the size of the families through migration toward other occupations.

\section{Monthly household expenditure}

On the same area of the previous analysis, the ENEP Rural produced a low or extremely low monthly household expenditure because three out of four producers declare expenses below ten thousand

${ }^{5}$ The average is the result of the relation between the 10417 people who "depend economically" on the producer and the $5232 \mathrm{PU}$ which according to the census, existed in Mexicali. Table 1 and 132 of INEGI (2008b). productor $^{4}$. Los valores obtenidos en cada uno de los casos (Cuadro 1) muestran que más de la mitad de los productores no superan los trescientos mil pesos anuales, de hecho, uno de cada cinco no alcanza cien mil, en el otro extremo apenas uno de cada diez supera el millón. Estos datos sostienen que la enorme mayoría de los productores de Mexicali, tres de cada cuatro, son de tamaño reducido, claramente insuficiente para la manutención decorosa a partir de su actividad agrícola.

\section{Tamaño de la familia}

La variable Tamaño de la Familia (Cuadro 2) aporta un dato claro, no son familias grandes, pues más del $70 \%$ no tiene más de cuatro miembros y solo uno de cada veinte tiene más de siete. Estos datos son similares a la información que arroja el Censo que promedia tres miembros, el productor y dos dependientes económicos 5 . Así que, es importante subrayar que las familias rurales con actividad agrícola no son numerosas como podría haberse presumido o incluso documentado años atrás, es

${ }^{4} \mathrm{El}$ ingreso neto (resultado de restar los costos de producción individuales al valor de la producción agrícola) es la medida más acertada, en la realidad la obtención de estos datos es de extrema dificultad.

${ }^{5}$ El promedio resulta de la relación entre las 10417 personas que son "dependientes económicos" del productor y las 5232 UP que, según el Censo, existían en Mexicali. Cuadros 1 y 132 de INEGI (2008b). 
Table 3. Mexicali. Monthly Household Expenditure

Cuadro 3. Mexicali. Gasto familiar mensual

\begin{tabular}{cc}
\hline $\begin{array}{c}\text { Monthly expenditure (pesos 2008)/ } \\
\text { Gasto mensual (pesos 2008) }\end{array}$ & $\begin{array}{c}\text { Household / } \\
\text { Familias (\%) }\end{array}$ \\
\hline 700 & 41 \\
1000 to $5000 / 1000$ a 5000 & 34 \\
5001 to $10000 / 5001$ a 10000 & 7 \\
10001 to $15000 / 10001$ a 15000 & 9 \\
15001 to $20000 / 15001$ a 20000 & 1 \\
20001 to $25000 / 20001$ a 25000 & 0.5 \\
35000 & 0.5 \\
40000 & 0.5 \\
60000 & 7 \\
\hline$N C / N S$ & 7 \\
\hline
\end{tabular}

Source: Elaboration from ENEP Rural (2009). *NC=Did not answer/NS=Does not know

Fuente: Elaboración a partir de ENEP Rural (2009).

pesos: in two out of five their level is below five thousand pesos. At the highest end, hardly $3 \%$ mentions expenses above thirty five thousand pesos. It is not possible to obtain similar information form the Census (Table 3).

\section{Main problems of the producers}

Assuming that the primary activity is the basis of the producers income, the problems they face become decisive, the information obtained from the field work shows that the first declared problem is the cost of the supplies such as, fertilizers, fuels, seeds (Table 4), the second problem in order of importance, is related to water for irrigation purposes, regarding its cost and obtaining it inopportunely and at insufficient volumes. The Agricultural and Livestock Census also detects the cost of the inputs as a primary problem, and the second most critical one is access to loans, which can be seen in Table 126 of the basic tabulators of INEGI's Census (2008b).

If the main problem is seen taking into consideration the size of the producer, it can be pointed out that the problems accentuate in a natural manner, in smaller-size producers, as their production value increases, the problems decrease. However, it is sensible to highlight that the cost of supplies, the problems related to water supply, the lack of or insufficient loans or financing are still the fundamental difficulties of most of the producers (ENEP Rural, 2009). altamente probable que los bajos niveles del valor de la producción y los altos costos de los insumos tenga un efecto reductor en el tamaño de las familias a través de la migración a otras ocupaciones.

\section{Gasto familiar mensual}

En el mismo terreno del análisis anterior, la ENEP Rural arroja un bajo, o extremadamente bajo, gasto familiar mensual, pues tres de cada cuatro productores declaran erogaciones por debajo de los diez mil pesos: en dos de cada cinco su nivel es inferior a cinco mil pesos. En el extremo superior, apenas $3 \%$ señala gastos por encima de los treinta y cinco mil pesos. Del Censo no es posible obtener información similar (Cuadro 3).

\section{Principales problemas del productor}

Suponiendo que la actividad primaria es la base del ingreso del productor, resultan determinantes los problemas a los que se enfrenta, la información obtenida del trabajo de campo muestra que el primer problema declarado es el costo de los insumos, tales como fertilizantes, combustibles, semillas (Cuadro 4), el segundo problema en importancia es lo relativo al agua de riego, tanto lo concerniente al costo, como a su obtención a destiempo y volumen insuficiente. El Censo Agropecuario también detecta el costo de los insumos como problema primario, y el segundo más crítico es la accesibilidad crediticia, esto puede 


\section{Age and Gender of the producer}

Even though the 2007 questionnaire of the Census gathers information about the age of the producer, in the tabulator and reports, tables of data are not published nor separated by municipalities, the ENEP Rural acquires this differentiated information by gender, from the interviewed producers, without observarse en el Cuadro 126 de los tabulados básicos del Censo de INEGI (2008b).

Si se observa el problema principal tomando en cuenta el tamaño del productor, se puede señalar que los problemas se acentúan de manera natural, en los productores de menor tamaño, conforme el valor de su producción se eleva, los problemas

Table 4. Mexicali: Main problem of the producer

Cuadro 4. Mexicali: Principal problema del productor

\begin{tabular}{lc}
\hline \multicolumn{1}{c}{ Problem / Problema } & Producers \% / Productores \% \\
\hline Input cost/ fertilizers/seed/electricity/fuels / & 23 \\
Costo de insumos/ fertilizantes/semilla/ electricidad/ combustibles & 19 \\
Water/cost/opportunity/volume / & 15 \\
Agua/costo/oportunidad/volumen & 15 \\
Timely, sufficient, varied support / & 14 \\
Apoyos oportunos, suficientes, variados & 10 \\
Loans/financing / Crédito/financiamiento & \\
Harvest prices/Commercialization/ Partial payments / & 9 \\
Precios de cosecha/Comercialización/ Pagos parciales & \\
Machinery/Equipment/Facilities/Hydraulic infrastructure / & \\
Maquinaria/Equipo/Instalaciones/Infraestructura hidráulica & 5 \\
Without problems / & \\
Sin problemas & 4 \\
Low quality plot/Uneven/Pests/Yields / & \\
Parcela de baja calidad/Desnivelada/Plagas/ Rendimientos & \\
Technical assistance/Insurance / & 0.5 \\
Asistencia técnica/Aseguranza & \\
Vandalism / & \\
Vandalismo & \\
\hline
\end{tabular}

Source: Elaboration from ENEP Rural (2009).

Fuente: Elaboración a partir de ENEP Rural (2009).

Table 5. Mexicali: Age of the producer by gender with productive activity Cuadro 5. Mexicali: Edad de productor por género con actividad productiva

\begin{tabular}{cccc}
\hline \multirow{2}{*}{ Age / Edad } & \multicolumn{3}{c}{ \% of Producers / \% de Productores } \\
\cline { 2 - 4 } & $\mathbf{F}$ & $\mathbf{M}$ & Total \\
\hline $29-30$ & 50 & 50 & 1 \\
$31-40$ & 14 & 86 & 11 \\
$41-50$ & 23 & 77 & 15 \\
$51-60$ & 19 & 81 & 22 \\
$61-70$ & 14 & 86 & 23 \\
$71-80$ & 22 & 78 & 19 \\
$81-90$ & 50 & 50 & 3 \\
Total & & & 100 \\
\hline
\end{tabular}

Source: Elaboration from ENEP Rural (2009).

Fuente: Elaboración a partir de ENEP Rural (2009). 
a doubt the proportion of women hardly signify one out of five producers, regarding ages of both genders, these are concentrated in the range on fifty to eighty years old. A relevant fact is the high proportion of elderly producers whose ages go from seventy to eighty years old (Table 5) this shows a significant and preoccupying proportion of elderly producers whose replacement can be affected by the low capacity of the activity to sustain rural families.

\section{Schooling by gender of the producer}

Having been shown masculine prevalence in the rural property and as main producers, the schooling variable (Table 6) shows critical conditions: the Agricultural and Livestock Census shows that in half of the PU the level of schooling of the producer is primary or less, which can be seen in Table 131 in the tabulator of the Census (INEGI, 2008b), ENEP Rural coincides finding that half of the producers studied any grade of primary school. It is also important to point out the non-despicable reality that one out of five producers have a college degree, this does not mean they are better prepared to carry out the activity because the type of profession is not necessarily technically related to it. The census only shows that one out of seven PU have producers with the schooling grade "other", which possibly means a grade higher than high school. Retaking these data, a low level of schooling of the rural producers can be inferred derived from the disadvantage agricultural activities have on the capacity to support a family and the small-size or low-scale most of the producers have. disminuyen. Sin embargo, es prudente resaltar que los altos costos de insumos, los problemas relacionados con el suministro de agua, la falta o insuficiencia de apoyos y la insuficiencia de crédito o financiamiento siguen siendo las dificultades fundamentales de la generalidad de los agricultores (ENEP Rural, 2009).

\section{Edad y género del productor}

A pesar de que el cuestionario del Censo de 2007 recoge información sobre la edad del productor, en los tabulados e informes no se pulican cuadros de datos y menos desagregados a nivel municipal, la ENEP Rural obtiene esta información diferenciada por género, de los productores entrevistados sin duda sobresale la proporción de mujeres que significan apenas uno de cada cinco productores, en cuanto a edades de ambos géneros éstas se concentran en el rango de los cincuenta a los ochenta años. Un dato relevante es la alta proporción de productores de edad avanzada que va de los sesenta a los ochenta años (Cuadro 5) lo cual evidencia una significativa y preocupante proporción de productores de edad avanzada cuyo reemplazo puede verse afectado por la baja capacidad de la actividad para dar sostenimiento a las familias rurales.

\section{Escolaridad por género del productor}

Habiendo quedado señalada la preponderancia masculina en la propiedad rural y como productores titulares, la variable de escolaridad (Cuadro 6) refleja condiciones críticas: el Censo Agropecuario muestra que en la mitad de las UP el nivel de estudios del productor es la primaria o menos, lo cual puede verse

Table 6. Mexicali. Schooling of the producer by gender Cuadro 6. Mexicali. Escolaridad del productor por género

\begin{tabular}{cccc}
\hline \multirow{2}{*}{ Grade / Grado } & \multicolumn{3}{c}{ \% of Producers / \% de Productores } \\
\cline { 2 - 4 } & $\mathbf{F}$ & $\mathbf{M}$ & Total \\
\hline Without/ Sin & 17 & 83 & 15 \\
Primary / Primaria & 17 & 83 & 46 \\
Secondary / Secundaria & 28 & 72 & 15 \\
High school / Preparatoria & 26 & 74 & 12 \\
College / Profesional & 17 & 83 & 12 \\
Total & & & 100 \\
\hline
\end{tabular}

Source: Elaboration from ENEP Rural (2009).

Fuente: Elaboración a partir de ENEP Rural (2009). 
Complementary occupations of the producer

Even though the major income of the producer comes from an Agricultural activity, it does not explain the total income to support themselves and their families, they generally have additional incomes from complementary activities, the Agricultural and Livestock Census gathers data about the origin of their income (Table 128 of INEGl's tabulator, 2008b) and it finds that in one fourth of the PU, its producers obtain complementary income from "another activity", from remittances and government support, whereas the ENEP Rural show that one third of the producers complement their income with non-agricultural activities such as, mechanics, welders, storekeepers, they depend on the primary production.

\section{Professionalization or technical training}

of the producer

The initial data obtained from ENEP Rural seems discouraging: only one out of ten producers have a profession or technical studies (the Agricultural and Livestock Census does not include information regarding en el Cuadro 131 de los tabuladores del Censo (INEGI, 2008b), por su lado la ENEP Rural es coincidente al encontrar que con algún grado de primaria se encuentran la mitad de los productores. También es importante señalar la nada despreciable realidad de que uno de cada cinco productores alcanzó un nivel universitario sin que esto signifique mejor preparación para desarrollar la actividad debido a que el tipo de profesión no está necesariamente relacionada técnicamente con ella. El Censo solo arroja la cifra de que una de cada siete UP tiene productores con el grado escolar "otro", presumiblemente grado por encima de preparatoria. Retomando estos datos, se puede advertir un bajo nivel de escolaridad en los productores rurales derivado de las condiciones de desventaja que la capacidad de sustento familiar tienen las actividades agrícolas y el menor tamaño o baja escala que la gran mayoría de los productores tienen.

\section{Ocupaciones complementarias del productor}

Aun cuando la presunción lógica del ingreso del productor es mayoritariamente derivado de su

Table 7. Mexicali: Occupations of the producer

Cuadro 7. Mexicali: Ocupaciones del productor

\begin{tabular}{lc}
\hline Occupation / Ocupación & $\%$ \\
\hline Farmer / Agricultor & 64 \\
Home / Hogar & 12 \\
Employee, Pensioner / Empleado, Pensionado & 13 \\
Mechanic, Welder, Turner, Coachbuilder, Storekeeper, Seamstress / & 8 \\
Mecánico, Soldador, Tornero, Carrocero, Comerciante, Costurera & 3 \\
\hline
\end{tabular}

Source: Elaboration from ENEP Rural (2009).

Fuente: Elaboración a partir de ENEP Rural (2009).

Table 8. Mexicali: Male and Female producers with a Profession /Technical Studies

Cuadro 8. Mexicali: Productores(as) con Profesión/Estudios Técnicos

\begin{tabular}{lc}
\hline Profession/Technician / Profesión/Técnico & $\%$ \\
\hline Agronomy Engineer, Veterinarian / Ing. Agrónomo, Médico Veterinario & 55 \\
Licentiate in Education, Pedagogy, Informatics, Accountant / & 25 \\
Lic. Educación, Pedagogía, Informática, Contador & 25 \\
Agricultural and Livestock, Commerce, Accounting Technician, Mechanic / & 20 \\
Técnico Agropecuario, Comercio, Contable, Mecánico & \\
Mechanical, Civil, Topographic, Chemical Engineer / Ing. Mecánico, Civil, Topógrafo, Químico & \\
\hline
\end{tabular}

Source: Elaboration from ENEP Rural (2009).

Fuente: Elaboración a partir de ENEP Rural (2009). 
the professional or technical profile), but precisely, that is why it is transcendental, because the institutional effort must be set on increasing the number of trained producers, from this scarce portion, only a little bit more than a half of them are agricultural and livestock professionals, mainly agronomists (Table 8 ).

\section{Occupations of other family members}

The occupation of the family members provides a clue about the eventual labor direction that the next generation is taking, the analysis of the data obtained from the ENEP Rural is revealing, it highlights the predominance of the student condition, but still in a low proportion, since it is only one out of three. It is important to observe that one out of six persist on continuing in the agricultural activity as a "farmer", this number can be understood as the social proportion that would stay in the activity, in front of the primary production of the region (Table 9), the Agricultural and Livestock Census only offers data regarding the number of people in the family who "participated in agricultural and livestock activities", but support on simple conditions, it does not distinguish if they could be preparing for the generational relay as producers.

\section{Professionalization or technical training of family members}

On the same sense of the previous demographic characteristic, analyzing the family profile from the actividad agrícola, ello no explica totalmente su manutención y la de su familia, generalmente tiene entradas adicionales por actividades complementarias, el Censo Agropecuario recoge datos sobre el origen de ingreso (Cuadro 128 de tabulados INEGI, 2008b) y encuentra que en una cuarta parte de las UP, sus productores obtienen ingresos complementarios de "otra actividad", de remesas y por apoyos gubernamentales, por su lado, los datos de la ENEP Rural muestran que un tercio de los productores complementan su ingreso con actividades distintas a la producción agropecuaria, aunque no necesariamente desconectadas (Cuadro 7), pues varias de estas ocupaciones como mecánicos, soldadores, comerciantes, dependen de la producción primaria.

\section{Profesionalización o capacitación técnica del productor}

El dato inicial obtenido por la ENEP Rural parece desalentador: solo uno de diez productores son profesionistas o tienen algún estudio técnico (el Censo Agropecuario no contempla información sobre el perfil profesional o técnico), pero precisamente por ello es trascendente, pues el esfuerzo institucional debe estar empeñado en elevar el número de productores con capacitación, de esta escasa proporción solo un poco más de la mitad son profesionistas agropecuarios, agrónomos fundamentalmente (Cuadro 8).

Table 9. Mexicali. Occupation of other family members

Cuadro 9. Mexicali. Ocupaciones de otros miembros de la familia

\begin{tabular}{lc}
\hline Occupation / Ocupación & $\%$ \\
\hline Student / Estudiante & 37 \\
General Labor Worker, Female Cook, Public, Factory, Secretaries / & 15 \\
Empleado Labores Generales, Cocinera, Público, Fábrica, Secretarias & 14 \\
Farmer / Agricultor & 13 \\
Administrator, Accountant, Communicator, Lawyer, Doctor, Dentist, Engineer, Teacher / & 8.5 \\
Administrador, Contador, Comunicador, Abogado, Médico, Dentista, Ingeniero, Maestra & 7 \\
Mechanic, Painter, Operator, Welder, Refrigeration, Technician, Supervisor, Construction Worker / & 5 \\
Mecánico, Pintor, Operador, Soldador, Refrigeración, Técnico, Supervisor, Albañil & 5 \\
Momemaker / Hogar & \\
Comerciante, Productor de Cine, Cultora de Belleza, Estilista, Llantero & 0.5 \\
Migrant in the U.S. / Migrante en EE. UU. &
\end{tabular}

Source: Elaboration from ENEP Rural (2009).

Fuente: Elaboración a partir de ENEP Rural (2009). 
Table 10. Mexicali: Professions/Technical Studies of other family members

Cuadro 10. Mexicali: Profesiones/Estudios Técnicos de otros miembros de la familia

\begin{tabular}{lc}
\hline Profession/Technician / Profesión/Técnico & $\%$ \\
\hline Licentiate in Business Administration, Accounting, Computer Science, Marketing, Systems / & 38 \\
Lic. Administración de Empresas, Contabilidad, Computación, Mercadotecnia, Sistemas & 26 \\
Lawyer, Psychologist, Licentiate on Physical Education, Nurse / & 13 \\
Lic. Derecho, Psicología, Lic. Educación Física, Enfermería & 12 \\
Civil Engineer, Electrician, Mechanic; Architect, Graphic Designer. / & 6 \\
Ing. Civil, Eléctrico, Mecánico, Arquitecto, Diseño Gráfico & 5 \\
Secretary, Commerce/ Secretariado, Comercio & 5 \\
Teaching, Educator, Teacher / Docencia, Educadora, Maestra & \\
\hline
\end{tabular}

Source: Elaboration from ENEP Rural (2009).

Fuente: Elaboración a partir de ENEP Rural (2009).

variable of profession or technical training can offer a perspective on the direction the next generation is taking related to the primary activity as origin. Data of the ENEP Rural show signs of distancing, firstly, on choosing a profession or technical training: agricultural and livestock professions are practically absent, the preference for administrative majors is significant (Table 10), this decision can be understood as a distancing process of subsequent generations from agriculture as a livelihood. Regarding the Census, it does not take into consideration this type of information.

\section{Conclusions}

It is crucial to recognize that there is an aggravated difficulty due to the lack of regional information about the socio-demographic conditions of the rural subjects in the Northern part of Mexico, studies about this topic are scarce and receive little o no funding, the census as well as the survey carried out by INEGI do not focus on the rural subject but on the Production Units and the socio-demographic information they gather is remarkably limited. This lack of knowledge about the regional reality of the producers and their families severely restricts understanding the problems of development, it is necessary to open studies and lines of research about these areas of social reality and for institutions carrying out these activities such as Public Research Centers and Universities to receive resources to carry out these activities which are and will become

\section{Ocupaciones de otros miembros de la familia}

La ocupación de los miembros familiares ofrece pista sobre la eventual dirección laboral que la siguiente generación está tomando, el análisis de los datos obtenidos en la ENEP Rural es revelador, destaca la predominancia de condición de estudiante, pero aún en baja proporción, pues es solo uno de cada tres. Algo importante de observar es que uno de cada seis persiste en continuar en la actividad agrícola, como "agricultor", este número podría entenderse como la proporción social que estaría quedándose en la actividad, al frente de la producción primaria de la región (Cuadro 9), el Censo Agropecuario solo ofrece datos sobre el número de personas de la familia que "participaron en las labores agropecuarias", pero en condiciones simples de apoyo, no distingue si ellos podrían estar preparándose para el relevo generacional como productores.

Profesionalización o capacitación técnica de miembros de la familia

En el mismo sentido de la característica demográfica anterior, analizar el perfil familiar, desde la variable de profesión o capacitación técnica, puede ofrecer una perspectiva de la dirección que toma la siguiente generación respecto de la actividad primaria como origen. Los datos de la ENEP Rural muestran indicios de distanciamiento en un primer plano en la elección de profesión o capacitación técnica: las profesiones agropecuarias están prácticamente ausentes, la preferencia por carreras administrativas 
more relevant to plan the agricultural and rural development.

The ENEP Rural gathers information that offers a more complete socio-demographic profile than the one gathered by the 2007 Agricultural, Livestock and Forestry Census, the latter is the last one carried out, there are not more, the new ENAs have the same distancing regarding the generation of socio-demographic knowledge and also suffers discontinuity.

From the comparative descriptive analysis of the variables, the largest proportion of agricultural land rights that persisted as producers have a smaller size to the extent of having a production value that is clearly not enough to support their families and to a lesser extent to obtain profit, families whose number of family members is also reduced, the levels of the family expenditure in almost all of the cases is clearly low, to the extent of setting doubts about the degree of well lbeing or migration.

It is also transcendental to mention that the cost of inputs, fertilizers and proper water for irrigation and in a sufficient volume are the most mentioned problems that affect producers of this region.

Another delicate warning is the high dominance of elderly producers and a low proportion of the generational replacement, families and subsequent generations search for a different livelihood than that of the primary activity, as a matter of fact, the numbers showed during the survey process as cases of producers that persisted in the activity, is a clear sign of the migration of rural families towards other forms of livelihood far from the agricultural activity.

The level of schooling and technical preparation is still shocking, the low level and reduced proportion in most of the producers does not indicate that they are gaining agricultural preparation, nor academic or technical.

It is important to mention that the field work offered a reality with high difficulty to find producers, one of the conditions that determined this situation was the aggravated lag on documentary and legal updating of owners or rural land-holders, so from the 704 total number of cases that formed the sample, it was not possible to locate 234 producers and 195 of them were appropriate to answer the questionnaire es significativa (Cuadro 10), esta decisión puede entenderse como un proceso de alejamiento de las generaciones subsecuentes de la agricultura como modo de vida. Con relación al Censo, no contempla información de esta naturaleza.

\section{Conclusiones}

Es de crucial importancia reconocer que existe una dificultad agravada por la falta de información regional de las condiciones sociodemográficas de los sujetos rurales en el norte mexicano, los estudios en este ámbito son muy escasos y reciben poco o nulo financiamiento, tanto los censos como las encuestas de INEGI no enfocan al sujeto rural sino a las Unidades de Producción y la información sociodemográfica que recogen es notablemente limitada. Esta ausencia de conocimiento sobre la realidad regional de los productores y sus familias restringe severamente el entendimiento de los problemas del desarrollo, es necesario abrir líneas de estudio e investigación sobre estas áreas de la realidad social y que instituciones dedicadas a ello como Centros Públicos de Investigación y Universidades reciban recursos para realizar estos trabajos que son y van cobrando mayor importancia para la planeación del desarrollo agrícola y rural.

La ENEP Rural obtiene información que ofrece un perfil sociodemográfico más completo que el que recoge el Censo Agrícola, Ganadero y Forestal de 2007, y este es el último llevado a cabo, no hay más, las nuevas ENA tienen el mismo distanciamiento en materia de generación de conocimiento sociodemográfico y también han padecido la discontinuidad.

Del análisis descriptivo comparado de las variables, se puede subrayar que la mayor proporción de los derechos de predios agrícolas que persistieron como productores tienen un tamaño menor, a tal grado que el valor de su producción agrícola es claramente insuficiente para la manutención de sus familias, mucho menos para obtener utilidades, familias cuyo número de miembros es también reducido, los niveles del gasto familiar en casi la totalidad de los casos es claramente bajo, al grado de plantear dudas sobre el grado de bienestar o de marginación. 
because they had persisted in the agricultural activity in the 2007 cycle. Due to this reality, the exercise carried out in this study must take this into consideration, as well as the fact that there is no information with the required thoroughness and thematic or geographical differentiation, nor ideally updated, nor with official statistics or in research studies. The analysis and reflections here presented is an effort based on field data that objectively have value to plan the agricultural and the rural region development.

\section{End of English version}

\section{References / Referencias}

Calvo, R., \& Aguado, J. A. (2012). Aportaciones a la construcción de un modelo de desarrollo local: la experiencia del Ayuntamiento de Catarroja. Gestión y Análisis de Políticas Públicas, núm. 7, enero-junio, 2012, pp. 149-172. Instituto Nacional de Administración Pública Madrid, España.

Colef, Produce B. C. (2008). El Colegio de la Frontera Norte A.C., Fundación Produce para la Investigación Agropecuaria, Forestal y Pesquera de Baja California. Estudio de estratificación regional de productores del sector rural de los municipios de Baja California. México.

Conagua. (2008). Comisión Nacional del Agua, Gerencia Estatal en B.C., Padrón de Usuarios del Distrito de Riego 014 Río Colorado. México.

ENEP Rural. (2009). Encuesta Estatal a Productores Rurales de los municipios de Baja California. Base de datos sociodemográficos, El Colegio de la Frontera Norte A. C., Mexicali, México.

Gómez, L., \& Tacuba A. (2017). La política de desarrollo rural en México. ¿Existe correspondencia entre lo formal y lo real? Economía UNAM vol. 14 núm. 42, septiembrediciembre 2017.

INEGI. (2008a). Instituto Nacional de Estadística, Geografía e Informática. VIII Censo Agrícola, Ganadero y Forestal 2007. Aspectos metodológicos y principales resultados. México.

INEGI. (2008b). Instituto Nacional de Estadística, Geografía e Informática. VIII Censo Agrícola, Ganadero y Forestal 2007. Tabulados básicos. México.
También es trascendental señalar que los costos de los insumos, fertilizantes y agua con oportunidad y volumen suficiente son los problemas de mayor mención que afectan a los productores de esta región.

Otra advertencia delicada es la alta predominancia de productores de edad avanzada y una proporción reducida que apunta como reemplazo generacional, las familias y las generaciones subsecuentes buscan un modo de vida distinto a la actividad primaria, de hecho, los números señalados en el levantamiento como casos de productores que persistieron en la actividad, es un claro indicio de la migración de las familias rurales a otros modos de vida alejados de la actividad agrícola.

El nivel de escolaridad y preparación técnica es aún alarmante, su bajo nivel y reducida proporción en la mayoría de los productores no permite afirmar que van ganando preparación, ni escolar, ni técnica, para la agricultura.

Es importante señalar que el trabajo de campo ofreció una realidad con alto grado de dificultad para la localización de los productores, una de las condiciones que determinaron esta circunstancia fue el rezago agravado en la actualización documental, legal, de los propietarios o titulares de los predios rurales, de tal manera que del total de 704 casos que integraron la muestra no fue posible localizar a 234 productores y 195 de ellos fueron procedentes para la aplicación del cuestionario en función de haber persistido en la actividad agrícola en el ciclo 2007. Debido a esta realidad, el ejercicio hecho en este trabajo debe tener en cuenta eso, también que no existe más información con la profundidad y desagregación temática y territorial necesarias, tampoco con la actualización ideal, ni en estadísticas oficiales ni en trabajos de investigación. El análisis y las reflexiones que aquí se presentan es un esfuerzo de aproximación con base en datos de campo que tienen, objetivamente, valor para la planeación del desarrollo agrícola y rural regionales.

Fin de la versión en español 
INEGI. (2009). Instituto Nacional de Estadística, Geografía e Informática. VIII Censo Agrícola, Ganadero y Forestal 2007. Síntesis metodológica. México.

INEGI. (2013). Instituto Nacional de Estadística, Geografía e Informática. Encuesta Nacional Agropecuaria 2012. México.

INEGI, (2018). Instituto Nacional de Estadística, Geografía e Informática. Encuesta Nacional Agropecuaria 2017. Conociendo el campo de México. Resultados. México.

Leyva, J. C., Gastélum, D. A., \& López, C. (2015). Análisis sociodemográfico de los municipios del estado de Sinaloa, México, bajo un enfoque multicriterio. Gestión y Política Pública. Volumen XXVI, Núm. 2, II Semestre de 2015, pp 533-577.

Méndez, R. I., Namihira, G. D, Moreno, A. L., \& Sosa, DM. C. (1993). El protocolo de investigación. Lineamientos para su elaboración y análisis. 2a ed, Editorial Trillas, reimpresión 1993. ISBN 968-24-4100-5. México.

Sánchez, O. (Compilador). (2003). Monografía de Mexicali y su Valle 1903-2003. Ayuntamiento de Mexicali, B.C., México. p.54.

SARH. (1976). Secretaría de Agricultura y Recursos Hidráulicos. Obras de rehabilitación del Distrito de Riego núm. 14 Río Colorado, Baja California y Sonora, Dirección General de Irrigación y Control de Ríos, México. Citado en: Zavala, J., 2010. Cambios en el comportamiento productivo en las unidades de producción rural del
Valle de Mexicali: los censos agropecuarios de 1991 y 2007. Revista mexicana de economía agrícola y de los recursos naturales, Universidad Autónoma Chapingo, División de Ciencias Económico-Administrativas. Vol. III, Núm. 2, Julio-diciembre. México. 49-67.

Schejtman A., \& Berdegué, J. (2004). Desarrollo territorial rural. Rimisp-Centro Latinoamericano para el Desarrollo Rural. Recuperado de: https://www.rimisp. org/wp-content/files_mf/1363093392schejtman_y_ berdegue2004_desarrollo_territorial_rural_5_rimisp_ CArdumen.pdf

SRA. (2008). Secretaría de Reforma Agraria, Delegación en B.C. Listado de Ejidos de B.C., listado de colonias agrícolas y ganaderas y de terrenos nacionales de los municipios de B.C. México.

Torres, H. (2006). Información demográfica y políticas públicas a escala regional y local. En: Rodríguez, V. J. 2006. Reunión de expertos sobre insumos sociodemográficos para la gestión y el desarrollo local. CELADE División de población, Serie Seminarios y Conferencias Núm. 48. Octubre, 2006. Chile. pp 33-53.

Zambrano, F., Trujillo, E., \& Solórzano, C. S. (2015). Desarrollo rural sostenible: una necesidad para la seguridad agroalimentaria en Venezuela. Aibi revista de investigación, administración e ingeniería, Volumen 3, Número 1 de 2015, p. 27-33. 